\title{
Locations of Cinnabar-Mercury Occurrences in Peru: Implications for Pre-Contact Gold Production
}

\author{
William E. Brooks \\ Geologist, Reston, VA, USA \\ Email: webgeology@aim.com
}

How to cite this paper: Brooks, W. E. (2020). Locations of Cinnabar-Mercury Occurrences in Peru: Implications for Pre-Contact Gold Production. Archaeological Discovery, 8, 245-259. https://doi.org/10.4236/ad.2020.83014

Received: May 28, 2020

Accepted: June 26, 2020

Published: June 29, 2020

Copyright ( $\odot 2020$ by author(s) and Scientific Research Publishing Inc. This work is licensed under the Creative Commons Attribution International License (CC BY 4.0).

http://creativecommons.org/licenses/by/4.0/

\section{(c) (i) Open Access}

\begin{abstract}
The Huancavelica cinnabar-mercury occurrence is the most well-known, but not the only, cinnabar-mercury occurrence in Peru. Therefore, a compilation of the approximately 20 other cinnabar-mercury occurrences is important in assessing the regional availability of this important mineral and its industrial uses in pre-contact Peru. These include: 1) cinnabar use as an ancient red pigment and, 2) more importantly, retorting cinnabar was an important source of mercury that was used for pre-contact alluvial gold amalgamation and, later Colonial silver amalgamation. Geochemical sampling of the lesser-known Chonta occurrence also indicates $\mathrm{Ag}, \mathrm{Pb}-\mathrm{Zn}$, or $\mathrm{Au}$ exploration targets. Retorting cinnabar has been widely documented and dates to 8000 years ago in ancient Turkey; during Roman time; in ancient Mexico; medieval Europe; the western US; and Indonesia. Using only cinnabar, clay for the ceramic retorts, and charcoal, coal, or other fuels, this artisanal process provided the mercury that was essential to the small-scale gold mining technology that produced tons of gold from alluvial sources before the arrival of the Spanish explorers in ancient South America. In present-day Peru, mercury is used to produce tons of gold from small-scale mines, and by analogy, the tons of gold produced in pre-contact Peru are hard evidence that is consistent with small-scale gold mining and mercury amalgamation in the past.
\end{abstract}

\section{Keywords}

Cinnabar, Mercury, Retort, Amalgamation, Andes

\section{Introduction}

Cinnabar (HgS) is an important mineral with two important uses in the ancient world: 1) it can be selectively ground and used as a versatile red pigment for use 
on murals, ceramics, and gold masks (Petersen, 1970/2010; Brooks et al., 2008) or, 2) it can be retorted to produce mercury (Cabrera la Rosa, 1954; Craddock, 1995; Brooks, 2012). Retorting cinnabar to obtain mercury has been documented more than 8000 years ago in ancient Turkey (Barnes \& Bailey, 1972; Brooks et al., 2017); during Roman time (Pliny the Elder, 77AD); the Middle East (al-Hassan \& Hill, 1986), in ancient Mexico (Langenscheidt, 1986); medieval Europe (Agricola, 1556/1912); and California in the 1840s (Bailey \& Everhart, 1964).

The primary present-day use of mercury worldwide is for alluvial gold mining; however, other modern uses include: auto switches, batteries, chlor-alkali production, dental amalgam, and fluorescent lamps. Therefore, since cinnabar was mined and retorted for mercury in the past, it is logical to conclude that mercury would have been used for that same purpose in the past-alluvial gold mining.

An example of the importance of mercury in alluvial gold mining is indicated by the production of approximately 26,000,000 pounds (or 342,000 seventy-six pound flasks) of mercury from New Almaden and other California mercury mines that were used to amalgamate alluvial gold during the California Gold Rush in 1849 (Davis, 1957; Bailey \& Everhart, 1964; Bailey et al., 1973; Lanyon \& Bulmore, 1967; Alpers et al., 2005). Similarly, mercury produced from Alaskan cinnabar mines was essential to the Klondike Gold Rush in 1896 (National Park Service, 2019). Mercury is used widely today to produce gold in Colombia, Ecuador, Ghana, Peru, Venezuela, Indonesia, and many other countries. Alluvial gold was the main source of gold for ancient man and provided two-thirds of the gold ever produced (Boyle, 1979).

\section{Gold Production}

Gold is produced in only two ways, the oldest of which is small-scale mining of alluvial or placer gold deposits using gravity separation combined with mercury. In Peru, alluvial gold deposits are widespread and the most well-known are Marañon in northeastern Peru; Rio Huallaga in east-central Peru; and Madre de Dios in southeastern Peru (Noble \& Vidal, 1994; Atlas, 1999). The sparse nuggets found in streams could easily be removed by hand; however, the ages-old method of amalgamation uses gravity separation by washing the gold-bearing sediment in a pan to produce an initial separate of black sand that includes mm-sized gold flakes (chispitas), magnetite, apatite, and other heavy minerals. Then mercury is added to this heavy-mineral concentrate to selectively remove, or amalgamate, only the gold. Next, the gold-mercury amalgam is burned (refogado) to volatilize most of the mercury leaving an anthropogenic sponge-like gold nugget that could be worked for artifact production.

Cyanide is the second method used to extract gold; however, this method only dates to the 1880s. Gold and other precious metals are removed in solution from the pulverized ore from large-scale, hard-rock porphyry ( $\mathrm{Au}-\mathrm{Cu}-\mathrm{Ag}$ ) mines. In 
pre-contact Peru, porphyry ores would have provided a gold-copper-silver alloy (tumbaga), which through depletion gilding would have resulted in enhanced surficial gold (Petersen, 1970/2010).

\section{Availability and Use of Mercury in the Andes}

In South America, cinnabar-mercury occurrences are known in Bolivia (Ahlfeld \& Schneider-Scherbina, 1964), Chile (McAllister et al., 1950), Colombia (Wilson, 1941; Lozano, 1987; Brooks, 2014), Ecuador (Truhan et al., 2005), and Peru (Arana, 1901; Garbín, 1904; Yates et al., 1955; Petersen, 1970/2010; Giles, undated). The most well-known occurrences include Huancavelica, Peru (Arana, 1901); Aranzazu (Nueva Esperanza) and El Cinabrio, Colombia (Singewald, 1950; Buitrago \& Buenaventura, 1975; Brooks, 2014); and Azogues, Ecuador (Brooks, 2018).

Regarding gold production and the use of mercury in pre-contact Peru, Garcilaso de la Vega commented that "Gold was gathered by the Incas from the streams ... no idea of the virtues of quicksilver" (Prescott, 1847/2005). While it is true that the gold came from alluvial sources, his conclusion regarding mercury is not supported.

Given, the wealth of gold produced in pre-contact Peru and the geological availability of cinnabar-mercury occurrences, Posnansky (1945/1957) was the first to propose the use of cinnabar as a source of mercury (azogue) for small-scale alluvial gold mining in the ancient Andes. Cabrera la Rosa (1954) concluded that: "Asimismo es posible suponer que los peruanos de aquellas tierras conocián, ya en épocas remotas, el método de la amalgamación, empleando para ello el azogue que lograban obtener del cinabrio cuyas menas existián en Buldibuyo". Larco Hoyle (2001) also concluded that "...el beneficio de oro es todavía primitivo ... incluyendo el empleo del azogue, que fue usado desde muy remota antigüedad'. Ravines (1978) refined Cabrera la Rosa's Buldibuyo location and indicated that "...azogue se encuentra en Buldibuyo al pie del gran nevado de Pelagatos". Petersen (1970/2010) said that “...data suggest that mercury was retorted from cinnabar”. And, by using modern analytical methods, Brooks et al. (2013) showed that comparable low levels of mercury in ICP (Inductively Coupled Plasma) analyses of pre-contact gold artifacts and modern refogado gold, where mercury is used, are consistent with mercury amalgamation of alluvial gold in the past.

The tons of gold produced in pre-contact Peru is hard evidence that is consistent with these assertions, and even today, Peru produces approximately 1.5 tons of gold per month from small-scale alluvial gold mines that use the same, ages-old rudimentary technique of mercury amalgamation of mm-sized alluvial gold (Cánepa, 2005; Brooks et al., 2007; Chauvin, 2018). During 2007-2011, Peru produced 16 - 22 tons of gold from small-scale alluvial gold mines, mainly in Madre de Dios, using mercury (Gurmendi, 2012).

Retorting and the use of mercury in ancient Peru may also be inferred from 
warnings regarding the toxic fumes released during the refogado process and effects on human health (Larco Hoyle, 2001), as well as the Quechua word llimpi which means mercury (Petersen, 1970/2010). In ancient through-to-modern time in Peru and elsewhere, the primary use of mercury is for small-scale alluvial gold mining.

\section{Map Compilation}

Huancavelica is the most well-known cinnabar-mercury occurrence in Peru (Arana, 1901; Whitaker, 1941; Yates et al., 1955; Brown, 2001) followed by the lesser-known Chonta-Queropalca occurrences (Garbín, 1904; Deustua, 2010). Therefore, a map showing these and other occurrences is basic to understanding the regional availability of this mineral resource, whether used for pigments or as a source of cinnabar for retorting mercury. Peruvian mineral resource maps were available for gold, copper, silver, and lead-zinc occurrences, but not cinnabar-mercury (Atlas, 1999); however, approximately 20 occurrences are given in Petersen (1970/2010). Many of these occurrences might be called districts because they include numerous mines and workings, such as the 10 mines at Chonta and the 15 mines at Queropalca (Garbín, 1904). And, in most cases, since only geographic names were given, and not latitude and longitude, the locations of these occurrences are approximate. These locations were compiled along with data from additional reports, some unpublished, and maps (Vercelli et al., 1977; Cobbing et al., 1996) from the Instituto Geológico Minero y Metalúrgico (INGEMMET) library in Lima (Figure 1).

The term "occurrence" is used herein to broadly indicate any geochemical anomaly of the mineral and includes mines as well. Many of the occurrences may indeed have been ancient mines for pigments or mercury but they have been obscured or overprinted by modern mining. There is no present-day primary mercury production in Peru from the occurrences given in Figure 1. However, mercury is produced as a byproduct from porphyry copper-gold mines such as Pierina and Yanacocha and, because of environmental considerations, this byproduct mercury is exported for treatment and retirement (Brooks et al., 2007).

Buldibuyo/Pelagatos/Pampas (2) site visit-Cabrera la Rosa (1954) indicated a cinnabar occurrence near Buldibuyo. Examination of the geologic report for the area did not list a mercury occurrence (Balarezo, undated); however, the report by Ravines (1978) did include "Buldibuyo" as being near Pelagatos in central Peru, and near the village of Pampas. This occurrence is important given the specific geographic reference provided by both Cabrera la Rosa (1954) and Ravines (1978). Additionally, it is near Pataz where pre-Inca and Inca alluvial gold production has been documented (Zarate, 2006). In Figure 1, this occurrence is indicated as Buldibuyo/Pelagatos/Pampas.

After leaving Pampas along a road paralleling Lago Pelagatos, cinnabar samples were taken at a fault with abundant rusty water and pyrite. An outcrop with cinnabar was found along this northwest-trending fault that extended for several 


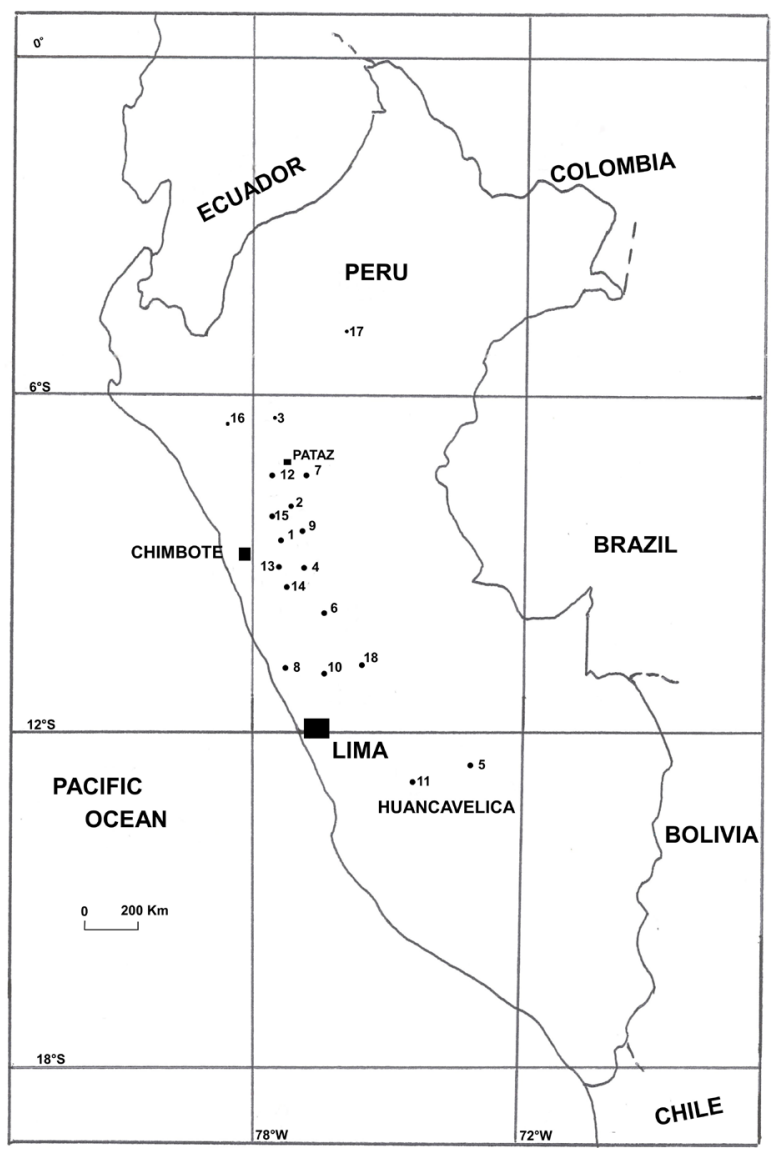

Figure 1. Approximate ${ }^{\star}$ locations of cinnabar-mercury occurrences in Peru. 1) Baños de

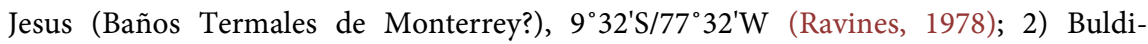
buyo/Pelagatos/Pampas, $8^{\circ} 07^{\prime} \mathrm{S} / 77^{\circ} 23^{\prime} \mathrm{W}$ (Cabrera La Rosa, 1954; Ravines, 1978); 3) Chachapoyas (Sonche?), 6 ${ }^{\circ} 13^{\prime} \mathrm{S} / 77^{\circ} 52^{\prime} \mathrm{W}$ (Bolétin, 1900; Petersen, 1970/2010; Ravines, 1978; Deustua, 2010). "Pinturas rupestre de Pollurua ... color rojo ocre" may indicate the use of cinnabar pigment; 4) Chonta/Huallaca/Queropalca, $12^{\circ} 38^{\prime} \mathrm{S} / 74^{\circ} 26^{\prime} \mathrm{W}$ (Petersen 1970/2010; more than 15 named mines are noted at Queropalca by Garbín, 1904; Giles, undated); 5) Chuschi, $13^{\circ} 35^{\prime} \mathrm{S} / 74^{\circ} 21^{\prime} \mathrm{W}$ (Petersen, 1970/2010); 6) Cuipan/Cuypan/Quipan, $10^{\circ} 30^{\prime} \mathrm{S} / 76^{\circ} 29^{\prime} \mathrm{W}$ (INGEMMET, 1999; cinnabar was taken from "bocaminas $y$ socavones antiguos" at Cuipan which is $\sim 30 \mathrm{~km}$ northwest from Cerro de Pasco, Garbín, 1904; Giles, undated); 7) Huacrachuco, $8^{\circ} 30^{\prime} \mathrm{S} / 77^{\circ} 04^{\prime} \mathrm{W}$ (Petersen, 1970/2010); 8) Huara,

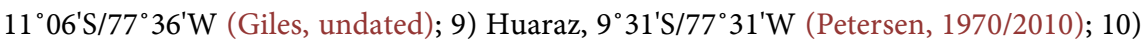
Huarochiri, $11^{\circ} 50^{\prime} \mathrm{S} / 76^{\circ} 22^{\prime} \mathrm{W}$ (Petersen, 1970/2010); 11) Huancavelica/Villa Rica de Oropesa/Santa Barbara, $12^{\circ} 47^{\prime} \mathrm{S} / 74^{\circ} 54^{\prime} \mathrm{W}$ (Arana, 1901; Yates et al., 1955; Petersen, 1970/2010; Brown, 2001; locations and descriptions of other mines and prospects in the region that include: Camarada, Excelsior, Carniceria, Azulcocha, Chaqa Oreco/Ventanilla 7, Huajoto, Torres Orgo, San Antonio, and Pequeña are given in INGEMMET, 1999); 12) Paccha, $7^{\circ} 59^{\prime} \mathrm{S} / 77^{\circ} 42^{\prime} \mathrm{W}$ (Petersen, 1970/2010); 13) Pampas, 9 ${ }^{\circ} 40^{\prime} \mathrm{S} / 77^{\circ} 49^{\prime} \mathrm{W}$ (Petersen,

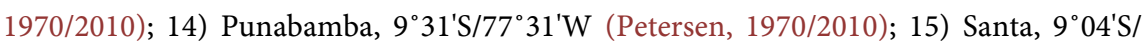
$78^{\circ} 35^{\prime} \mathrm{W}$ (Petersen, 1970/2010); 16) Santa Apolonia, $7^{\circ} 09^{\prime} \mathrm{S} / 78^{\circ} 31^{\prime} \mathrm{W}$ (Petersen, 1970/2010); 17) Santa Cruz, $5^{\circ} 33^{\prime} \mathrm{S} / 75^{\circ} 48^{\prime} \mathrm{W}$ (Petersen, $\left.1970 / 2010\right)$; 18) Yauli, $11^{\circ} 40^{\prime} \mathrm{S} / 76^{\circ} 05^{\prime} \mathrm{W}$ (Petersen, 1970/2010); The following occurrences are not shown on the map: 19) Azoguine, $15^{\circ} 45^{\prime} \mathrm{S} / 70^{\circ} 01^{\prime} \mathrm{W}$ (INGEMMET, 1999); 20) Carachugo/Cajamarca, $7^{\circ} 09^{\prime} \mathrm{S} / 78^{\circ} 30^{\prime} \mathrm{W}$ (INGEMMET, 1999); 21) Cangallo/Minascucho/Chauschi, $13^{\circ} 37^{\prime} \mathrm{S} / 74^{\circ} 08^{\prime} \mathrm{W}$ (INGEMMET, 1999). ${ }^{\star}$ All locations are approximate and are based on information given in the references cited. 
kilometers (Figure 2). The fault was iron-stained and rusty water drained from the fault. Pyrite was also found along the fault and decomposition of the pyrite is the likely source of the rusty water. Two samples contained $24-82 \mathrm{ppm}$ mercury (Table 1) and are well above the crustal average of $<0.08 \mathrm{ppm}$ for mercury (Turekian \& Wedepohl, 1961). Tungsten and other large-scale mining in the area limited further access and likely eliminated or overprinted any traces of ancient mines.

Table 1. ICP data for reconnaisance of Pelagatos and Chonta cinnabar-mercury occurrences, Peru.

\begin{tabular}{|c|c|c|c|c|c|c|c|c|}
\hline & PE181 & PE182 & PE191 & PE192 & PE193 & PE194 & PE196 & PE197 \\
\hline $\mathrm{Au}(0.003)$ & 0.008 & 0.007 & 0.01 & 0.004 & 0.006 & 0.018 & 0.072 & 0.010 \\
\hline $\operatorname{Ag}(0.2)$ & $<0.2$ & $<0.2$ & 7.6 & 24.9 & 10 & 18.8 & 24.6 & 199 \\
\hline As (2.0) & 27 & 7 & 2002 & 2178 & 87 & 84 & 824 & 6391 \\
\hline $\mathrm{Ca}(100.0)$ & 3948 & 13165 & 199 & 263 & $<100$ & $<100$ & 446 & $<100$ \\
\hline $\mathrm{Cd}(0.5)$ & $<0.5$ & $<0.5$ & 0.9 & 0.7 & $<0.5$ & $<0.5$ & 0.6 & $<109.8$ \\
\hline $\mathrm{Cr}(1.0)$ & 563 & 237 & 16 & 14 & 11 & 16 & 21 & 4 \\
\hline $\mathrm{Cu}(1.0)$ & 11 & 14 & 34 & 28 & 20 & 23 & 44 & 97 \\
\hline $\mathrm{Fe}(100)$ & 14,306 & 6029 & 175,434 & 76,827 & 350,000 & 114,282 & 37,609 & 335,325 \\
\hline $\mathrm{Hg}(0.5)$ & 82.9 & 24.9 & 13.1 & 11.9 & 10.7 & $>1000$ & $>1000$ & 93.6 \\
\hline $\mathrm{La}(10)$ & $<10$ & $<10$ & $<10$ & $<10$ & $<10$ & $<10$ & $<10$ & $<10$ \\
\hline $\mathrm{Mg}(100.0)$ & 2759 & 3483 & 154 & 116 & $<100$ & 102 & 232 & $<100$ \\
\hline $\operatorname{Mn}(5.0)$ & 108 & 51 & 56 & 89 & 43 & 109 & 102 & 24 \\
\hline Mo (1.0) & 4 & 1 & 2 & 3 & $<1$ & 2 & 2 & $<1$ \\
\hline $\mathrm{Ni}(1.0)$ & 15 & 20 & 5 & 8 & 5 & 9 & 12 & 6 \\
\hline $\mathrm{P}(10)$ & 295 & 105 & 565 & 216 & 22 & 25 & 76 & 17 \\
\hline $\mathrm{Pb}(3.0)$ & 37 & 5 & 4016 & 6394 & 665 & 370 & 134 & 15,535 \\
\hline S (100) & 904 & 244 & 6928 & 7619 & $>100,000$ & $>100,000$ & 31,977 & $>100,000$ \\
\hline $\mathrm{Sb}(3.0)$ & 6 & 3 & 174 & 248 & 77 & 23 & 21 & 367 \\
\hline $\mathrm{Se}(5.0)$ & $<5$ & $<5$ & $<5$ & $<5$ & $<5$ & $<5$ & $<5$ & 199 \\
\hline $\operatorname{Th}(10.0)$ & $<10$ & $<10$ & $<10$ & $<10$ & $<10$ & $<10$ & $<10$ & $<10$ \\
\hline $\mathrm{Tl}(5.0)$ & $<5$ & $<5$ & $<5$ & $<5$ & $<5$ & $<5$ & $<5$ & $<5$ \\
\hline $\mathrm{U}(8.0)$ & $<8$ & $<8$ & $<8$ & $<8$ & 20 & $<8$ & $<8$ & 17 \\
\hline $\mathrm{V}(1.0)$ & $<1$ & 7 & 73 & 47 & 1 & 2 & 2 & $<1$ \\
\hline W (3.0) & $<3$ & $<3$ & $<3$ & $<3$ & $<3$ & $<3$ & $<3$ & $<3$ \\
\hline $\mathrm{Zn}(1.0)$ & 5 & 5 & 339 & 201 & 36 & 31 & 72 & 9503 \\
\hline
\end{tabular}

Multi-element ICP analyses in parts per million (detection limit given to right of element, in parentheses, Au-fire-assay); American Assay, Sparks, NV [ICP-2A024-Pelagatos SP0124038; ChontaSP0130401]. Sample Descriptions: PE181 [0192625/9095652 UTM] Pelagatos, dark fg quartzite, spot sample along road parallel to lake, cinnabar exposed along $\mathrm{N} 30^{\circ} \mathrm{E}$ fault in roadcut, abundant pyrite and Fe-stained water; PE182 [0192625/9095652 UTM] Pelagatos, dark fg quartzite, area sample along road parallel to lake, cinnabar exposed along N $30^{\circ}$ fault in roadcut, abundant pyrite and Fe-stained water; PE191 [298130/8883304 UTM] Chonta, altered, quartzite, clay, along road at first main adit, area sample of $20 \mathrm{~m}$ wide breccia zone, altered with Fe stain; PE192 [298130/8883304 UTM] Chonta, at adit, area sample, vuggy, Fe stain; PE193 [298130/8883304 UTM] Chonta, at adit, float sample, dark, with pyrite; PE194 [738108/4293829 UTM] Chonta, quartzite, mine waste, with cinnabar on surface; PE196 [738108/4293829 UTM] Chonta, roadside, spot sample with cinnabar and pyrite; PE197[738108/4293829 UTM] Chonta, at mine near plant, spot sample with abundant pyrite. 


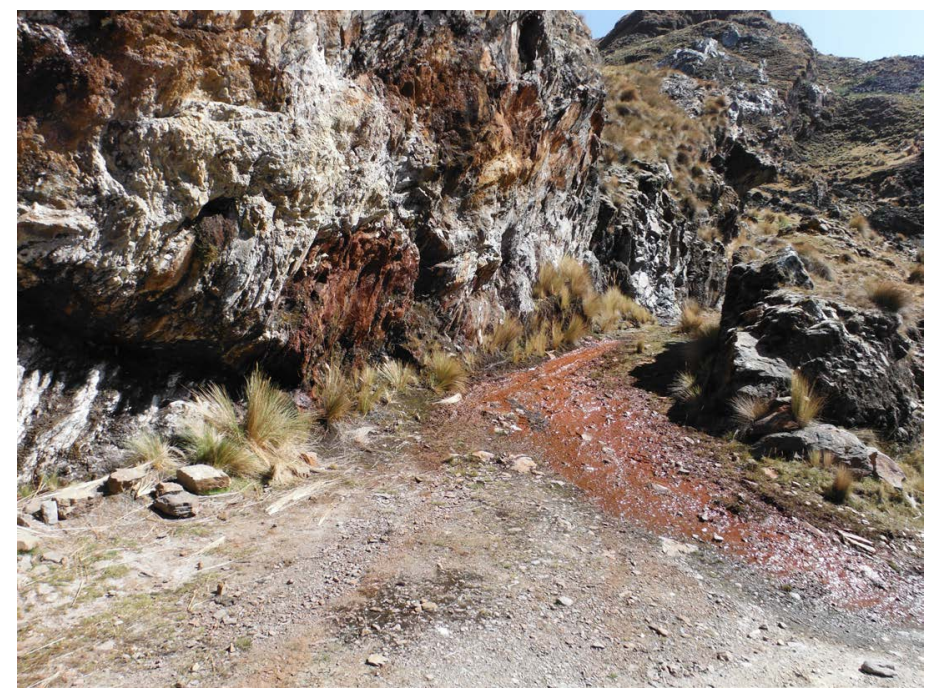

Figure 2. Samples of cinnabar were taken at northeast-trending fault along road that parallels Lago Pelagatos.

Chonta/Huallaca/Queropalca (4) site visit-The Chonta and Queropalca occurrences (Garbín, 1904; Giles, undated) may be accessed by a well-marked dirt road from Huallanca, to La Unión, and Baños. These occurrences were supposedly discovered upon orders from Spain in 1756 to find new sources of mercury to be used for Colonial silver amalgamation. However, it is very likely that these cinnabar-mercury occurrences were first known to pre-Inca people as a source of pigment as well as native mercury-early use of cinnabar as a red pigment by the Ohlone people in California led to the "discovery" of the New Almaden mercury mines in California by Spanish explorers (Lanyon \& Bulmore, 1967; Boulland \& Boudreault, 2006).

In the 1840s, there were over 2000 miners and more than 20 individual mines in the Chonta-Queropalca district (Figure 3). There were 11 retorts; fuels included locally available coal, peat, and a grass called ichu; and water for condensers came from a nearby lagoon, Chonta Cocha. The mines produced $8-10$ flasks (one flask contains $\sim 76$ pounds of mercury) of mercury per day. "Trabajos antiguos" may possibly indicate pre-contact mining; however, it is unclear as to the location or how old these workings might be. Similarly "bocaminas y socavones antiguos" may indicate pre-contact mining at the nearby Cuipan cinnabar occurrence (Garbín, 1904; Giles, undated). Chonta closed in 1843, however, not because the ore was exhausted, but because of opportunities for miners willing to immigrate and work at the mercury mines at New Almaden, California (Garbín, 1904; Giles, undated). This New Almaden mercury would be used for the California Gold Rush.

Minerals at the mines were hosted in quartzite and sedimentary rocks and include pyrite, sphalerite, galena, cinnabar, native mercury, and silver in mainly NS structures. Even the mine waste still contained silver and mercury and the grass roofs of the buildings collected droplets of mercury lost during retorting (Garbín, 1904). Some of the buildings still remain (Figure 4). 


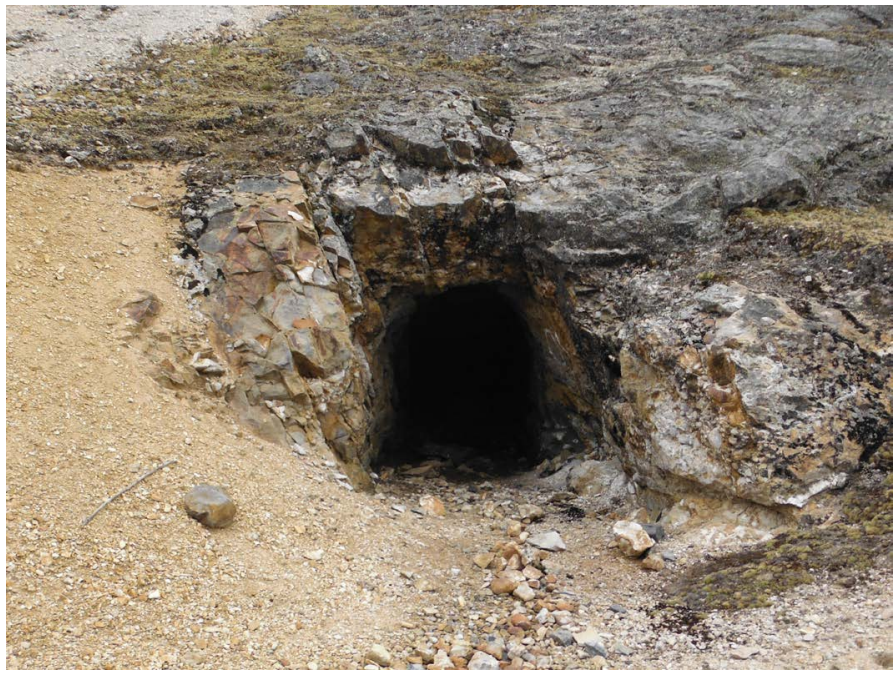

Figure 3. Mine entrance at Chonta, note vertical structure to right of entry.

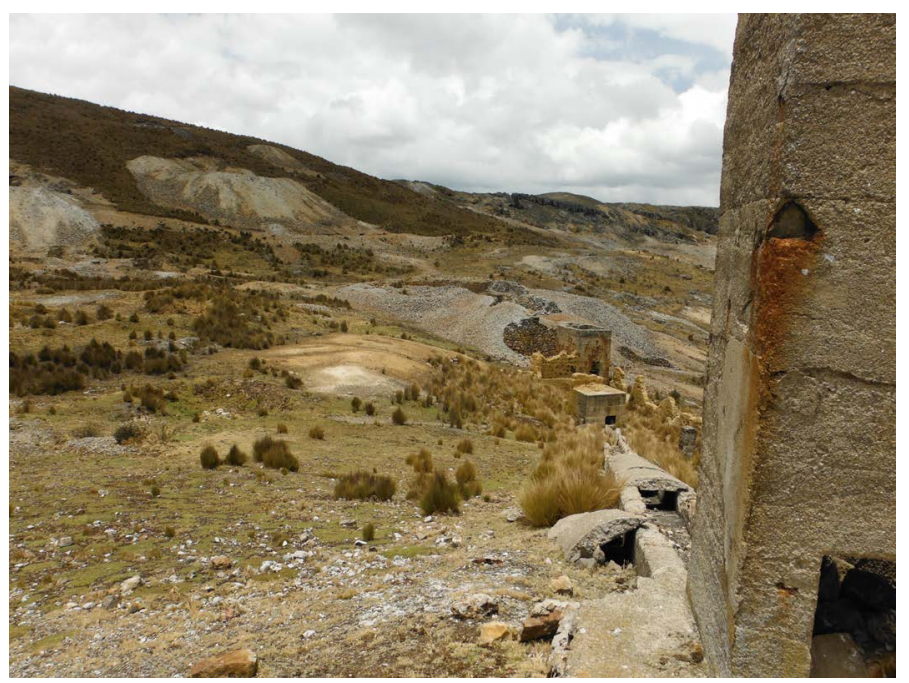

Figure 4. Buildings and tailings at Chonta, ground chimney and stack to right.

Samples from Chonta for this reconnaissance contained > 1000 ppm mercury; 10 - 199 ppm silver; 84 - 6391 ppm arsenic; 21 - 367 ppm antimony, and 31 $9503 \mathrm{ppm}$ zinc. Gold values are $0.01-0.07 \mathrm{ppm}$, but may increase with depth (Table 1). These elements are all above background and indicate further study focused on silver and gold in association with mercury (Turekian \& Wedepohl, 1961; Noble \& Vidal, 1990). Specifically, the high arsenic is a pathfinder for gold and the high mercury content is an indicator of lead-zinc-silver ore (Rose et al., 1979).

Queropalca was not visited for this study; however, numerous mercury mines were reported by Garbín (1904). Exploration drilling at Queropalca indicated several meters of gold-silver mineralization with values as high as $10 \mathrm{ppm}$ gold, $1500 \mathrm{ppm}$ silver, and $0.35 \%$ lead (mercury was not reported) (Candente Gold Corp., 2009). Veins and stockwork are hosted in quartzite. A hot-spring was mapped in the study area and this permits consideration of a hot-spring $\mathrm{Au}-\mathrm{Ag}$ 
exploration model for the district, especially given the high antimony and arsenic at Chonta (Berger, 1986; Candente Gold Corp., 2009).

Mercury was not produced at Huallanca, however, there are several large-scale mines at present-day Huallanca where mining dates to 1721 . Originally production was from three veins that produced gold, silver, and copper. Pyrite, chalcopyrite, sphalerite, and copper minerals are reported from well-named mines such as Komstock and Eureka (Garbín, 1904).

\section{Retorting Mercury from Cinnabar}

Retorting mercury is a straightforward process and requires cinnabar ore, retorts, fuel, and a condenser to trap and cool the volatilized mercury vapors. The oldest mercury retort dates to 8000 years ago in the ancient Konya mercury district in Turkey. It consisted of a large block of marble upon which the ore was placed along with charcoal fuel. A large clay bowl over the fire cooled and condensed the mercury vapors while allowing the sulfur to escape through a chimney comprised of ceramic tubes (Barnes \& Bailey, 1972). Other retorts include rows of double ceramic pots shown in Agricola's De Re Metallica (1556/1912, Book IX: p. 427) and a pre-contact double-ceramic mercury retort from Sierra Gorda, Queretaro, Mexico (Langenscheidt, 1986) where there are many ancient cinnabar mines and retorting mercury dates to the $10^{\text {th }}$ century BC (Consejo de Recursos Minerales, 1992). Descriptions and sketches of a variety of mercury retorts from China, Germany, and Mexico were compiled by Craddock (1995). Ancient mercury retorts are known at Huancavelica (Rivero \& Tschudi, 1853) and at Chonta, a chimney and buildings that housed retorts and condensers in the 1840 s remain (Figure 4 ).

At New Almaden, California the first retorts consisted of whaling oil-try pots that were inverted over the cinnabar ore, sealed, and then fired with wood. The cinnabar inside the metal pot was heated, the mercury volatilized, the vapors cooled and condensed, resulting in mercury (Boulland \& Boudreault, 2006). In Indonesia, up to a ton of mercury can be produced daily, using locally available cinnabar, from a simple, backyard wood-fired retort. This mercury is then sold directly to local small-scale gold miners or exported (Paddock, 2019).

Therefore, given the geological evidence for the regional availability of cinnabar-mercury occurrences and the widespread use of mercury for gold amalgamation in the past that continues to the present, it remains only to show how cinnabar could easily be retorted to obtain mercury using materials readily available in the ancient world. Therefore, a simple retort was modeled from the racks of double-ceramic retorts shown in Agricola's De Re Metallica (1556/1912, Book IX: p. 427) and a pre-contact double-ceramic mercury retort from Sierra Gorda, Queretaro, Mexico (Langenscheidt, 1986). This rudimentary process does not produce vermilion, only a sooty mercury-rich residue, and metallic mercury (Figures 5-8) that would have been collected and then used for ancient small-scale alluvial gold mining. 


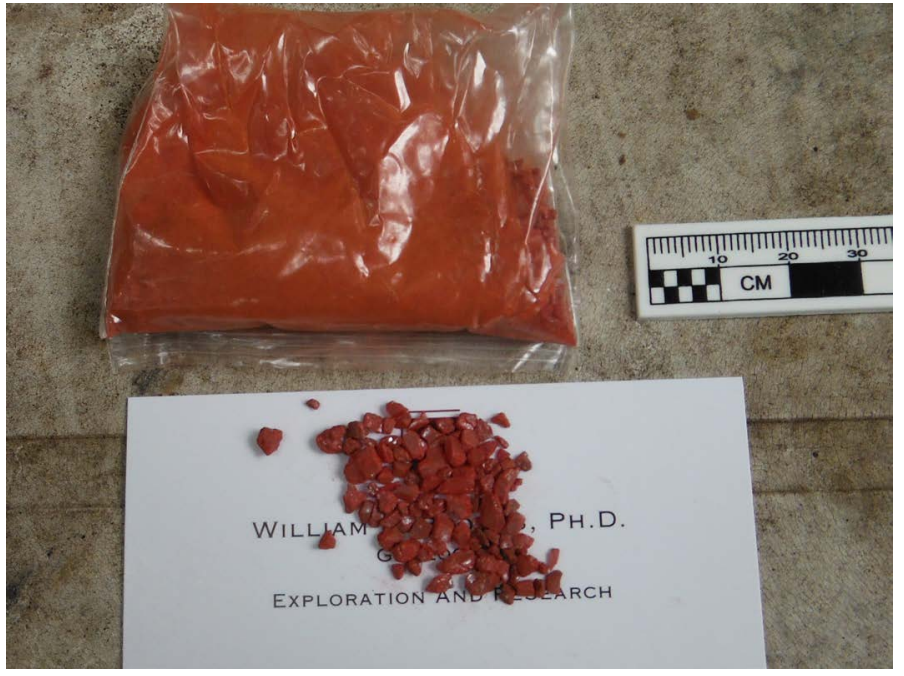

Figure 5. Cinnabar ore ( 50 g).

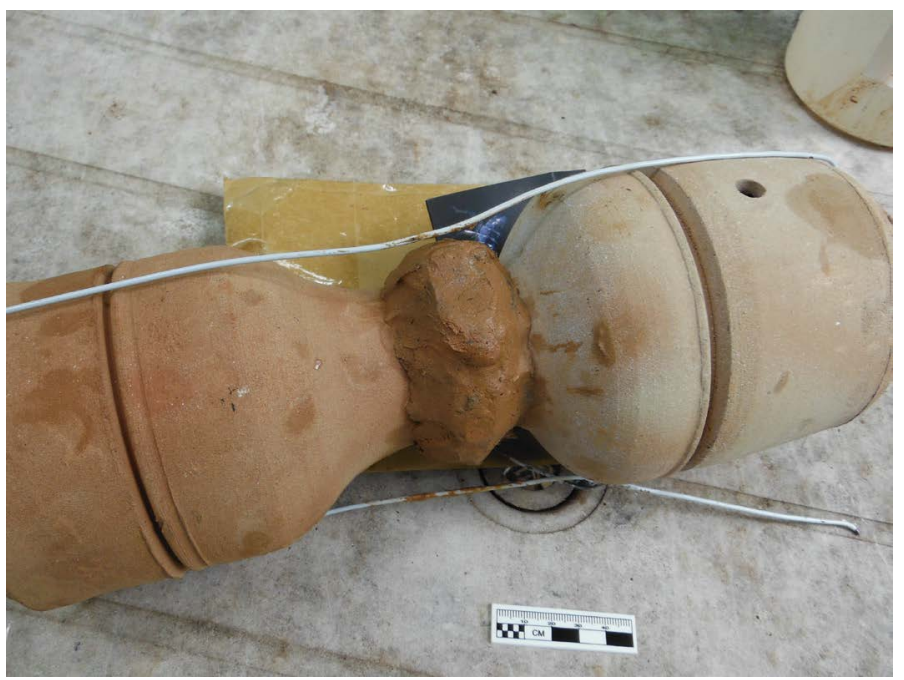

Figure 6. Double-ceramic retort with clay seal, vent to right.

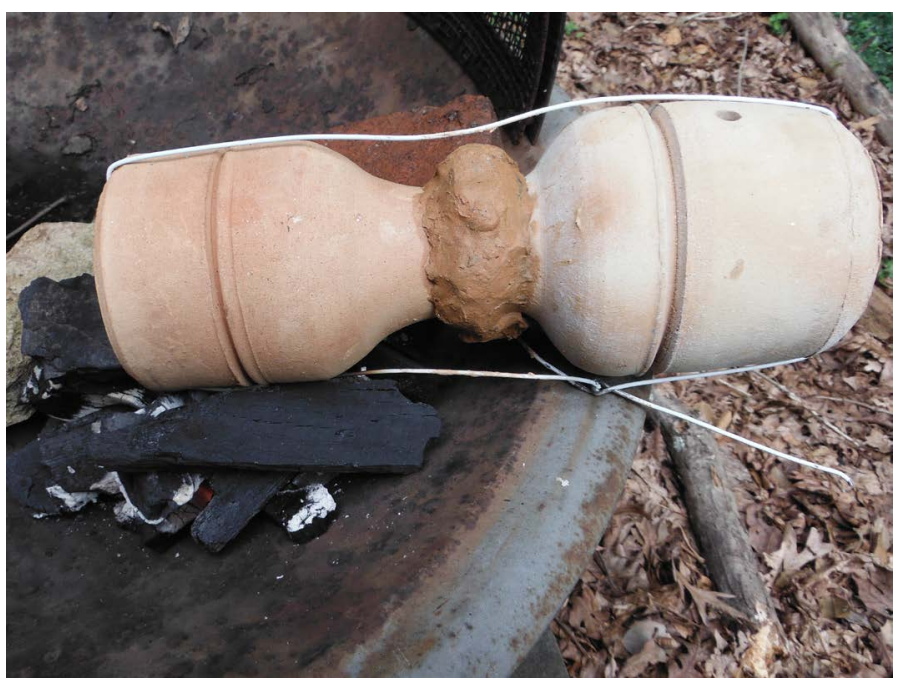

Figure 7. Retort in place with charcoal fuel $\left(\sim 600^{\circ} \mathrm{F}\right)$. 


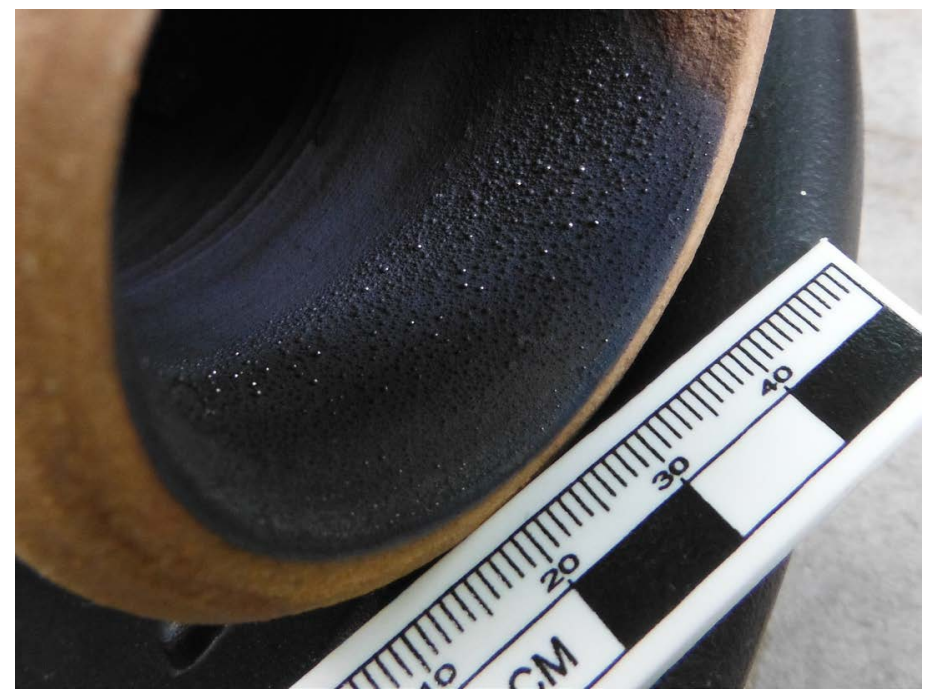

Figure 8. Mercury droplets in black mercury-rich residue along rim of ceramic retort. This black sooty residue in the retorts at New Almaden was scraped and removed to obtain additional mercury (Boulland \& Boudreault, 2006).

\section{Conclusion}

This compilation of cinnabar-mercury occurrences is important to the ongoing evaluation of the use of mineral resources in the ancient Andes. Huancavelica remains the most well-known occurrence, now followed by Chonta-Queropalca. The availability of cinnabar-mercury is especially applicable to the study of cinnabar sources and their uses, specifically as a source of red pigment and as a source of ore for mercury. Of these, the use of mercury for gold amalgamation helps to explain the technology that resulted in the incredible gold production that took place in ancient Peru before the arrival of the Europeans. In addition to ancient cinnabar mining at Huancavelica, there are suggestions of ancient workings at Chonta-Queropalca and Cuipan as well as evidence for pre-Inca gold mining at Pataz.

Native mercury was available, for example at Huancavelica or Chonta; however, retorting cinnabar was a relatively simple process that dates to ancient times. In Peru, retorting would have utilized readily available materials such as cinnabar ore, clay for ceramic retorts, water for cooling, and fuel such as wood, coal, or grass. Much as mercury is used today in Peru's small-scale alluvial gold mines in Madre de Dios or Marañon, in the past, mercury would have been sourced from the numerous cinnabar occurrences in Peru, retorted, and used for pre-contact gold production.

\section{Acknowledgements}

Sincere thanks are expressed to INGEMMET and especially to Sr. Rolando Moreno, director of the INGEMMET library, in Lima for providing maps and geologic reports on mercury in Peru. 


\section{VIDEO Links}

How to extract mercury from the cinnabar (singarf) para Rasmani

https://www.youtube.com/watch?v=3e9WrJSxrV4l

Rasamani Preparation Siddhar Methods Valairasam Using Lingam Pashanam https://www.youtube.com/watch?v=L5qIMjSwkJU

\section{Conflicts of Interest}

The author declares no conflicts of interest regarding the publication of this paper.

\section{References}

Agricola (1556/1912). De Re Metallica (638 p.). Trans. H. C. Hoover \&H. L. Hoover, NY: Kessinger Publishing.

Ahlfeld, F., \& Schneider-Scherbina, A. (1964). Los Yacimientos Minerales y De Hidrocarburos de Bolivia (388 p). La Paz, Ministerio de Minas y Petroleo, Departamento Nacional de Geología, Boletin No. 5 (Especial).

al-Hassan, A. Y., \& Hill, D. R. (1986). Islamic Technology: An Illustrated History (304 p). Cambridge: Cambridge University Press.

Alpers, C. N., Hunerlach, M. P., May, J. T., \& Hothem, R. L. (2005). Mercury Contamination from Historical Gold Mining in California. U.S. Geological Survey Fact Sheet 2005-3014. https://doi.org/10.3133/fs20053014

Arana, P. P. (1901). Las Minas de Azogue del Perú (109 p). Lima: Imprenta El Lucero.

Atlas (1999). Atlas of Mineria y Energía en el Peru (111 p.). Hokama, D., Ed., Lima: Ministerio de Energía y Minas.

Bailey, E. H., \& Everhart, D. L. (1964). Geology and Quicksilver Deposits of the New Almaden District, Santa Clara County, California (206 p). U.S. Geological Survey Professional Paper 360. https://doi.org/10.3133/pp360

Bailey, E. H., Clark, A. L., \& Smith, R. H. (1973). Mercury. In D. A. Brobst, \& W. P. Pratt (Eds.), United States Mineral Resources, U.S. Geological Survey Professional Paper 820 (pp. 401-414).

Balarezo, A. (undated). Croquis de Ubicación de Las Zonas Mineras de Parcoy y Buldibuyo. Lima: Cooperación Minera Peruano Alemana, INGEMMET Archivo Tecnico, Codigo CG1794, scale 1:1,000,000.

Barnes, J. W., \& Bailey, E. H. (1972). Turkey's Major Mercury Mine Today and How It was Mined 8000 Years Ago. World Mining, 25, 49-55.

Berger, B. R. (1986). Descriptive Model of Hot Spring Au-Ag, Model 25a. In D. P. Cox, \& D. A. Singer (Eds.), Mineral Deposit Models, U.S. Geological Survey Bulletin 1693.

Bolétin (1900). Itinerario de los Viajes de Raimondi en el Perú. Bolétin de la Sociedad Geográfica de Lima, 10, 1-40.

Boulland, M., \& Boudreault, A. (2006). New Almaden (225 p). Charleston, SC: Arcadia Publishing.

Boyle, R. W. (1979). The Geochemistry of Gold and Its Deposits. Canadian Geological Survey Bulletin, 280, 584 p.

Brooks, W. E., Ozturk, H., \& Cansu, Z. (2017). Amalgamation and Small-Scale Gold Mining at Ancient Sardis, Turkey. Archaeological Discovery, 5, 42-59.

https://doi.org/10.4236/ad.2017.51003 
Brooks, W. E. (2012). Industrial Use of Mercury in the Ancient World, Ch. 2. In M. S. Bank (Ed.), Mercury in the Environment: Pattern and Process (pp. 19-24). Berkeley, CA: Harvard School of Public Health, University of California Press. https://doi.org/10.1525/california/9780520271630.003.0002

Brooks, W. E. (2014). Colombia Mercury Inventory. Geología Colombiana, 37, 15-50.

Brooks, W. E. (2018). ICP Analyses from the Cinnabar-Mercury Occurrence at Azogues (Loma Guashon), Ecuador: Ancient Industrial Uses and Human Health Implications. Archaeological Discovery, 6, 38-51. https://doi.org/10.4236/ad.2018.61003

Brooks, W. E., Piminchumo, V., Suarez, H., Jackson, J. C., \& McGeehin, J. P. (2008). Mineral Pigments from Huaca Tacaynamo (Chan Chan, Peru). Bulletin de l'Institut Francais d'Études Andines, 37, 441-450. https://doi.org/10.4000/bifea.2957

Brooks, W. E., Sandoval, E., Yepez, M., \& Howard, H. (2007). Peru Mercury Inventory 2006. U.S. Geological Survey Open-File Report 2007-1252. https://doi.org/10.3133/ofr20071252

Brooks, W. E., Schwörbel, G., \& Castillo, L. E. (2013). Amalgamation and Small-Scale Gold Mining in the Ancient Andes, Ch. 10. In N. Tripcevich, \& K. J. Vaughn (Eds.), Mining and Quarrying in the Ancient Andes, Interdisciplinary Contributions to Archaeology (pp. 213-229). New York: Springer Publishing. https://doi.org/10.1007/978-1-4614-5200-3_10

Brown, K. W. (2001). Workers' Health and Colonial Mercury Mining at Huancavelica, Peru. The Americas, 57, 467-496. https://doi.org/10.1353/tam.2001.0030

Buitrago, C. J., \& Buenaventura, J. (1975). Ocurrencias minerales en la región central del departmento del Tolima (837 p). Bogotá: INGEOMINAS Informe 1672.

Cabrera la Rosa, A. (1954). Asimismo, es possible suponer que los peruanos de aquellas tierras conocián, ya en épocas remotas, el método de la amalgamación, empleando para ello el azogue que lograban obtener del cinabrio cuyas menas existián en Buldibuyo [Therefore, It Is Possible That the Peruvians from Those Areas Knew, in Ancient Time, the Method of Amalgamation, Using Azogue/Mercury That Was Obtained from Cinnabar Ores at Buldibuyo]. Situación Actual de la Minería del Mercurio en el Perú, Minería y Metalurgia, Madrid, 3-12.

Candente Gold Corp. (2009). Candente Gold Corporation Presentation. Vancouver, Canada: Candente Gold Corp. https://www.candentecopper.com/site/assets/files/5197/goldpropertiesapril2009.pdf

Cánepa, C. (2005). Minería a pequeña escala en la Costa Sur Media del Perú (62 p). INGEMMET Boletín 3, Lima: Instituto Geológico Minero y Metalúrgico.

Chauvin, L. (2018). Pope Brings His Environmental Crusade to Peru. Washington Post, 20 January, A8.

Cobbing, J., Sanchez, A., Martinez, W., \& Zarate, H. (1996). Geologia de los Quadrangulos de Huaraz, Recuay, La Union, Chiquian y Yanahuanca. INGEMMET Boletin n. 76, Serie A, Lima: Carta Geologica Nacional.

Consejo de Recursos Minerales (1992). Geological-Mining Monograph of the State of Queretaro (108 p). Mexico, D.F.: Consejo de Recursos Minerales, Secretaria de Energia, Minas e Industria.

Craddock, P. T. (1995). Early Metal Mining and Production (363 p). Washington DC: Smithsonian Institution Press.

Davis, F. F. (1957). Mercury. In L. A. Wright (Ed.), Mineral Commodities of California: California Division of Mines Bulletin 176 (pp. 341-356).

Deustua, J. E. (2010). Mercury (Not Always Rising) and the Social Economy of Nineteenth- 
Century Peru. Economía (Pontificia Universidad Católica del Perú. Departamento de Economía), 33, 128-153. http://www.researchgate.net

Garbín, L. (1904). Apuntes Sobre los Minerales de Huallanca, Chonta y Queropalca. Boletin de la Sociedad de Ingenieros, VI, 1-17.

Giles, C. F. (undated). Minas de Mercurio Conocidas en el Peru (3 p). Lima, Peru: INGEMMET Archivo Tecnico, Codigo 9921.

Gurmendi, A. C. (2012). The Mineral Industry of Peru. U.S. Geological Survey 2012 Minerals Yearbook.

https://minerals.usgs.gov/minerals/pubs/country/2012/myb3-2012-peru.pdf

INGEMMET (1999). Mercurio. INGEMMET Archivo Tecnico, Codigo AO993.

Langenscheidt, A. (1986). Historia Minima de la Minería en la Sierra Gorda, Queretaro, Mexico (pp. 24-29). Mineroamérica, abril, Mexico, D.F.

Lanyon, M., \& Bulmore, L. (1967). Cinnabar Hills, the Quicksilver Days of New Almaden (128 p). Los Gatos, CA: Village Printers.

Larco Hoyle, R. (2001). Los Mochicas, tomo II (350 p). Lima, Perú: Museo Arqueologíco Rafael Larco Herrera, Pueblo Libre.

Lozano, H. (1987). Minerales de Mercurio. Publicacciones Especial de Ingeominas, No. 1, Bogota, Colombia, 275-293.

McAllister, J. F., Flores, H., \& Ruiz, C. (1950). Quicksilver Deposits of Chile (69 p). U.S. Geological Survey Bulletin 964-E.

National Park Service (2019). Metals of the Gold Rush. National Park Service. https://www.nps.gov/klse/learn/nature/geology.htm

Noble, D. C., \& Vidal, C. E. (1990). Association of Silver with Mercury, Arsenic, and Antimony at the Huancavelica District, Peru. Economic Geology, 85, 1645-1650. https://doi.org/10.2113/gsecongeo.85.7.1645

Noble, D. C., \& Vidal, C. E. (1994). Gold in Peru. Society of Economic Geologists, SEG Newsletter, No. 17, 1-13.

Paddock, R. C. (2019). The Hidden Cost of Gold. New York Times, 9 November. https://www.nytimes.com/2019/11/09/world/asia/indonesia-mercury-pollution-gold-m ining.html

Petersen, G. (1970/2010). Mining and Metallurgy in Ancient Perú (90 p). Translation by W. E. Brooks, 2010, of Minería y Metalurgia en el Antiguo Perú, Arqueologicas 12, Museo Nacional de Antropología y Arqueología, Pueblo Libre, Lima, Perú. Geological Society of America Special Paper 467.

Posnansky, A. (1945/1957). Tiahuanaco, La Cuna del Hombre Americano. v. 1-II, 1945, New York; v. 3-4, Ministerio de Educación, 1957, La Paz, Bolivia.

Prescott, W. H. (1847/2005). History of the Conquest of Peru (537 p). Mineola, NY: Dover Publications.

Ravines, R. (1978). Tecnología Andina (821 p). Lima, Peru: Instituto de Estudios Peruanos, Instituto de Investigación Tecnológica Industrial y de Normas Técnicas, OCLC4263659.

Rivero, M. E., \& Tschudi, J. J. (1853). Peruvian Antiquities (225 p). New York,.

Rose, A. W., Hawkes, H. E., \& Webb, J. S. (1979). Geochemistry in Mineral Exploration (500 p). London: Academic Press.

Singewald, Q. E. (1950). Mineral Resources of Colombia, Geologic Investigations in the American Republics (pp. 151-155). U.S. Geological Survey Bulletin 964-B.

Truhan, D. L., Burton, D. L., \& Bruhns, K. O. (2005). El Cinabrio en el Mundo Andino. 
Revista de Antropología, 18, 193-205.

Turekian, K. K., \& Wedepohl, K. H. (1961). Distribution of the Elements in Some Major Units of the Earth's Crust. Geological Society of America Bulletin, 72, 175-192. https://doi.org/10.1130/0016-7606(1961)72[175:DOTEIS]2.0.CO;2

Vercelli, A., Paz, M., \& Huaman, A. (1977). Reservas Minerales en el Peru en Antimonio, Bismuto, Mercurio, Selenio, Tellurio, e Indio. INGEMMET Archivo Tecnico, Codigo A0717.

Whitaker, A. P. (1941). The Huancavelica Mercury Mine (150 p). Cambridge: Harvard University Press.

Wilson, F. (1941). Colombia. Engineering and Mining Journal, 142, 154-155.

Yates, R. G., Kent, D. F., \& Concha, J. F. (1955). Geology of the Huancavelica Quicksilver District, Peru (45 p). U.S. Geological Survey Bulletin 975-A.

Zarate, H. (2006). Proyecto GR5-Estudio Geológico del Batolito de Balsas-Pataz-Buldibuyo, Ocurrencias de la Mineralización en el Area de Estudio (110 p). INGEMMET Informe A5727, Lima, Peru. 